\title{
Relationship Between Flexible Working Arrangements and Job Satisfaction Mediated by Work-Life Balance: Evidence From Public Sector Universities’ Employees of Pakistan
}

Maha Aziz-Ur-Rehman (Corresponding Author)

Research Scholar

Karachi University Business School, University of Karachi, Pakistan

E-mail: mahaaziz12363@gmail.com

Dr. Danish Ahmed Siddiqui

Associate Professor

Karachi University Business School, University of Karachi, Pakistan

E-mail: daanish79@ hotmail.com

Received: Nov. 22, 2019 Accepted: Dec. 11, 2019 Online published: Dec. 16, 2019

doi:10.5296/ijhrs.v10i1.15875 URL: https://doi.org/10.5296/ijhrs.v10i1.15875

\begin{abstract}
The research focused on relationship between flexible working arrangements, work-life balance and job satisfaction in Karachi's public universities. To investigate the null hypothesis that there is no relationship between these variables. Research design is descriptive as we determine the association between dependent and independent variables. Independent variable is flexible working arrangements, which include: flexi-time, contractual working, work shifts and telecommuting, that are provided to employees to improve their productivity and maintain work-life balance. A structured questionnaire is designed to collect approximately 200-sample size via online and by university visits. Survey forms were distributed using random sampling method among more than nine different public universities of Karachi. The research is quantitative in nature and analyzed through CFA and SEM, using smart PLS. Findings show that flexible arrangements are significantly correlated with work-life balance. It also revealed that work-life balance is a strong mediator between
\end{abstract}


flexible arrangements and job satisfaction. Importance of flexible arrangements within an organization is highlighted in the recommendations to improve employees' satisfaction, their performance, work to family enrichment; hence, to increase productivity. Research included both quantitative and qualitative data and examined the relationship of flexible arrangements, work-life balance and job satisfaction from the view point of public universities.

Keywords: flexible working arrangements, flexible hours, contractual working, work shifts, telecommuting, work-life balance, job satisfaction, Pakistan

\section{Introduction}

The implementation of flexible arrangements programs presents an increasing popular business practice around the globe, as a reaction to socio-economic, demographic and gender role changes.

Flexible working relates to an organization working arrangement in terms of working time, working location and pattern of working (chartered institute of personnel and development). Flexible working arrangements like flexible part time, shift work, compressed work hours and job sharing are often used to help employees in balancing their family and work-life during 'core hours' which is usually fixed or a period between the latest permissible starting time and earliest permissible finishing time, cited by (Kipkoech V. K., 2017).

The concept of Work-life balance forces the issue that as human beings we are equitably committed with our employment and our private life with equal importance at both ends. It is about assisting employees to fulfill their working responsibilities along with their personal life commitments. It improves satisfaction, in both the professional as well as personal lives. The success of any institution is based on the performance of its staff, which in turn depends on various factors. Work-life balance is known as a foundation of job-satisfaction in service sectors like banking, education, etc. (Hafeez \& Akbar, 2015). The concept of job satisfaction is defined by Spector (1997) as an attitudinal variable, that represents the extent to which worker like or dislike his job.

Thus, to see outcomes of flexible arrangements many researches have been conducted. However, it appears that even though flexible work arrangements are universally acknowledged as beneficial both for employers and subordinates, are not yet successfully entrenched in public sector universities of Karachi city. Hence, it's important to work on different flexible arrangements especially in the educational sector to restore a work-life balance for the betterment of their staff performance, which ultimately aids in students education. It would be obtained by evaluating the role of work-family enrichment between flexible work arrangements and employees` job satisfaction.

\subsection{Background}

Programs where employees are provided with greater scheduling freedom, in how they fulfill the obligations of their positions, known as flexible work programs. Being most common flexible hours gives workers far greater leverage in terms of the time when they begin and end work. Other common flexible working arrangements involve telecommuting, job-sharing, 
work shifts, and compressed weeks.

Nowadays in corporate world, flexible time/place is continuously growing, to large extent as organizations introducing them, are continuously moving ahead, while at the same time enhancing the quality of life of their employees. In future, it seems clear that flexible work programs will continue to be used and be used more frequently. With the increasing demand of the Internet and rapid spread of high-speed connections to the Internet in homes and offices alike, the tools necessary to make flexible work programs successful are multiplying (Anonymous, Flexible Work Arrangements, 2008).

(Chung \& Der Lippe, 2018) said, especially from the younger generation, there is increasingly high demand for more flexibility in the workplace. Evidences proves that millennials would like the opportunity of telecommuting and/or have flexible hours. It is predicted, in future, rather than the exception, flexible working would become the norm, in most job.

Lack of balance between an employee's work commitments and their other responsibilities can lead ultimately to dissatisfaction. Employees with fair balance of work and family often have a greater sense of responsibility and control over both. A supportive employer can be rewarded by increased loyalty and commitment of his subordinates. It also helps to retain the talent and will reduce cost of turnover and recruitment (Anonymous, Flexible working and work-life balance, 2015).

\subsection{Research Problem}

Rapidly changing business environment requires specialized skills and innovative capabilities in workforce in order to compete accordingly. It imposes a challenge on employees to keep performing exceptionally well. Therefore, researches are required to find out factors that may positively affect employee's performance and productivity. Researches provide unique orientations to business organizations on how to capitalize their human resource more competitively and to the best of the company's advantage. Researches are important for the individual employee's learning opportunities as well as collective organizational innovative capabilities.

Hence, that is why this research have been undertaken as it scopes greater employee productivity through flexible work arrangements. Employees associated with service sector are prone to burnout and distress more frequently than manufacturing sector. Service sector relies on human skills and capabilities to serve the target market. Public universities' employees serve the future of business organizations in the form of fresh and qualified workforce; therefore, the research will be helpful to business community as whole.

\subsection{Gap Analysis}

Research conducted in oil and gas company, Dubai (Sumaiti, 2010) clearly identified significant correlation between the main variables. They also found teleworking as not only increase employees` satisfaction but also reduce fuel cost. However, the scope of the study was limited to one company of oil and gas. Considering teleworking and open office 
environment narrowed the scope as more flexibilities can also be studied.

Another study about effects of flexible time arrangements on employees' exhaustion, work-nonwork conflict and job performance by (Kattenbach, Demerouti , \& Nachreiner, 2010), was conducted among 17 different human service organizations in Germany, found negative impact of time-restrictions outweighs the positive outcomes of time-autonomy on work-nonwork conflict and well-being is an important indicator for practitioners in human resource management. However, the response rate was 63\%. 167 surveys were returned which is comparatively low as 17 companies were participated. Moreover, flexible time is the only flexibility considered in this research (e.g. flexible hours, compressed hours) and Low reliability of some scales is still a drawback of this study. Cronbach's alpha $<0.60$ is the minimum value requirement for research purpose.

A study conducted in Gujrat, Pakistan (Arif \& Aftab Farooqi, 2014) found that employees work-life balance affects employees`satisfaction and their commitments with organization. Teachers having balance in their work and life are more satisfied and; hence, are more productive, committed and loyal to organization. But the target population of this study was again limited as only one university and employee level is targeted. Moreover, areas covered for data collection were geographically specific. So, it is difficult to generalize the result.

Research conducted in a company of pharmaceutical industry, Spain by (Mas-Machuca, Mirabent, \& Alegre, 2016). They proposed that job autonomy and supervisor`s support both are positively related with work-life balance of employee which leads him towards organizational pride and; hence, increase job satisfaction. Considering only one pharmaceutical company narrowed its scope. Another limitation is antecedents i.e. job autonomy and supervisor`s support. which focused on employees` flexibility in how, where or when they define their daily work (i.e. flexible hours/place) and decision making in terms of organizing their work. Moreover, the degree of autonomy should also be considered as which and how much flexibilities should be given to employees that remain beneficial for both, employees and organization.

The relationship between work-life balance and job satisfaction is significant but how flexible working arrangements affects work-life balance and will it provide job satisfaction to employees, is not clarified, especially in public sector of education. Thus, our research is an attempt to investigate which type of flexibilities are required by employees of public universities and how they affect their work-life conflicts and job satisfaction. This study also focusses on four different flexibilities: flexible hours, work shifts, contractual working, and telecommuting altogether. Moreover, the research not only considered more than nine universities but also focused on all employee levels of public university, whether its top/lower management or employees from non-management staff. Thus, giving more accurate result about employees`responses.

\subsection{Research Objectives}

The aim of this research is to identify the relationship of flexible working arrangements with work-life balance and job satisfaction of employees of public universities. Service sector 
organizations utilize employees' creativity and potential to achieve short-term and long-term goals and objectives. Human is the key resource to service sector organization; therefore, it is vital to research on factors that may help in developing human resource. Moreover, public universities are responsible for the supply of competent and eligible workforce to be hired by business organizations. So, if public sector universities employees have been provided with flexible working arrangements and job satisfaction it would be likely that they have been serving students with strong integrity and high moral values.

To investigate the relationship between flexible working arrangements, work-life balance and job satisfaction of public university employees of Karachi city.

To identify whether balancing work and family life influence job satisfaction of public university employees.

\subsection{Research Questions}

Do the flexible working arrangements carry significant influence on work-life balance of employees?

Do the flexible working arrangements carry significant influence on job satisfaction of employees?

Does the work-life balance possess significant impact on employees` job satisfaction?

\subsection{Scope of the Study}

The research was conducted in more than nine different public universities of Karachi city in 2019. The study covered variables including: flexible hours, work shifts, contractual working, telecommuting, job satisfaction and work-life balance. The target population was the top, middle, lower and non-management employees as well which were randomly selected. The study adopted descriptive research design. The data was collected by administering closed ended questionnaire based on five Likert scales, 1 being strongly disagree and 5 strongly agree, where data were collected online through linked in and by visiting different universities of Karachi city. This allow humble time for data collection, analysis and discussion.

\subsection{Significance of the Study}

Certainly, flexible working arrangements are widely researched topic; however, due to great implications of this concept by the global companies, the research is required to be replicated in different sectors and industries. The research is particularly significant to business organizations operating in Karachi, Pakistan. It is likely that graduates and post graduates will be hired to serve the managerial layer of such organizations and these incumbents are outcome of universities. If future managers understand the variables that are responsible for their productivity and job satisfaction, they will use proactive approach in dealing with problems like distress, anxiety, inefficiency and burnout. This research will find out variables that are required to be improved for better execution of work-life balance. It will also be valuable for the public educational sector in order to improve their policies regarding their 
compensation packages, control systems and overall management of key human resource. The study is significant in highlighting that non-monetary work factors like flexible hours, contractual workings, work shifts, and telecommuting are a great source of employee motivation, productivity, efficiency and improved satisfaction. Employees (lower level) don't know much about job satisfaction and work-life balance which is certainly their fundamental right. As far as they have job, they are satisfied, rest of the things do not seem important to them. In public universities, this study can be utilized as guidelines, to pay attention to such variables, as its benefits are not only for teachers but can be good to universities in the long run.

\section{Literature Review}

\subsection{Flexible Working Arrangements}

Flexible arrangements are used as a tool or HR strategy of attracting, retaining and motivating key talented individuals. Employers encourage to offer these flexibilities due to the needs of workforce and changing environment, there are more dual earners, single parent families or women/men with elderly care responsibilities, (Choo, Desa, \& Abu Hassan Asaari, 2016).

(Gerdenitsch, Kubicek, \& Korunka, 2015) explained that employees are given more autonomy over their jobs (when and where to work) as fixed working is now replaced by schedule working practices, employees have more options as from where to do their task (e.g. café, home, plane) or within an organization (e.g. hotdesking). Sometimes, flexible working arrangements helps to increase job satisfaction and maintain work-life balance but often contributes to work augmentation and work-life conflicts. (Shagvaliyeva \& Yazdanifard, 2014) cited that employees are likely to retain with organizations that adopt flexible working arrangements because these practices define how much an organization cares about their well-being.

However, it was concluded that remote working was not found to decrease turnovers and transfers in general. The relationship between flexible work arrangements, job satisfaction and employee turnover in agencies is negative as no association was found. On other hand, it was found that alternative work schedule decreases turnover and transfers (Caillier, 2018). Support at work means organizational, supervisor and peer support, (Zeytinoglu, Denton, \& Millen Plenderleith, 2011). The term flexibility refers to both positive and negative imputes. One as strategic initiative of employers to increase the business requirements of the firm and other due to the demand of employees to balance work and life, (Wojcak, Bajzikovab, Sajgalikova, \& Polakova, 2016).

\subsubsection{Flexible Hours}

Flexi hours scheme offers the control to the beginning and ending of the work schedule. It facilitates employees to fulfil their non-labor commitments including childcare, household chores or personal activities, (Giovanis, 2018).

(Yang \& Zheng, 2011) explained family-oriented improvement program under flexible hours, 
where an employee could choose their starting and ending working hours and enjoy its benefits. Firstly, it is inferred that such employees work efficiently and effectively. Secondly, it helps in mitigating organizational problems like absenteeism, employee turnover and job stress. Thirdly, it improves employee's retention rate and; finally, it contributes to healthy and positive balance between personal and professional life. They also reported with all evidence that sometimes there a is positive link between flexible hours and productivity; sometimes, no association at all. It was concluded that the impact of flex-time on employees' productivity and performance must take into consideration of the organizational de-coupling of flex-time.

\subsubsection{Contractual Working}

Contingent working is another name of contractual workings. Under contingent workings, employees are hired on temporary and time bound contract, (Ashoush, Elsayed, \& Younis, 2015). According to (Kipkoech V. K., 2017), temporary contracts are hard to measure since its evaluation is based on the job to be done. There is no clear view on the benefits or cost attached to the contractual employment. This has created different views based on; lack of loyalty, insecurity, low esteem, high absenteeism and low productivity. Though it can be considered to evaluate the employee for further consideration and avoid wrong decisions taken by manager as well as used in job fluctuating industries to regulate balance or satisfy a job undertaking. (Dessler, 2008) added that it may be productive and cheaper in terms of recruitment and training, but the overall cost will increase by $20 \%$ to $50 \%$ as compared to some who is fixed employee (permanent).

One, who worked for a limited duration and expected by both sides to last for only a short time is contractual Worker. Based on definite period or the completion of a specific job or event, an employment contract. Notice for early termination must be contained in Fixed-term contracts. Thus, if circumstances change the contract can be ended by either party before the expiry date of the contract, (Flexible working and work-life balance, 2015).

\subsubsection{Work Shifts}

(Hinterseer, 2013) reported that the propensity towards more flexible arrangements is also revealed that only less than $47 \%$ of all workers in Austria have the same working hours every day. Only more than $51 \%$ have fixed times at work to begin and end. Employees within revolving job models and within work shifts contracts increased from $<14 \%$ to $19 \%$ between 1998 and 2008.

(Kipkoech V. K., 2017) reported that working in shifts helps in consuming more hours in a day by incorporating more than one shift; working day' for e.g. 3 blocks of 8 hours, 2 blocks of 8 hours, 2 blocks of 12 hours or some other variant advantage of shift-work is that it can provide 24 hours cover. It enables more human hours to be worked than the traditional day work system. It takes place outside the official working hours (8.30 a.m-5p.m) day. It can be in a form of night shift, evening, early morning or rotating shifts. This type of flexible work option is designed, so that the services in the hospital are provided 24/7, to make sure emergency issues are taken care of. According to International Labor Organization, work shifts helps the employees to improve one another at the workplace, so that the operations can 
operate longer than hours of work of a worker at day and night hours. Shift arrangement is vital practice since it helps in reducing accidents and fatigue, which realize in organization`s long run productivity.

\subsubsection{Telecommuting/Working From Home}

(Caillier, 2018) concluded that as teleworkers increases in agencies, the number of employees who quits decreases. He recommended to boost the utilization of teleworkers as it will not only enable them to handle work-family challenges but also reduce the percentage of employees quitting. But this arrangement of telecommuting will not reduce transfers, employees may feel as they are going to other agency, which might take care of employees' well-being, considering telework is available in all agencies. (Aguilera, Lethiais, Rallet, \& Proulhac, 2016) reported that telecommuting is fairly a restricted fact, generally it is an informal working arrangement as its advantages are paired with immediate disadvantages. The main purpose of this flexibility offered to staff is to decrease stress, burnout and fatigue. They further explained teleworkers as the people who do not work (on regular basis or not) from fixed location outside the office or area of employer; thus, self-employed individuals are not included here. According to (Wojcak, Bajzikovab, Sajgalikova, \& Polakova, 2016), thanks to information telecommunication technology that an employee can work at the customer's place, at home, in a means of transport or in a café, flight, or train. All these situations constitute the work arrangement in which the worker is considered to work 'from distance', i.e. as a teleworker.

\subsection{Work-Life Balance}

The concept of 'Work-life balance' or 'work-family conflict' introduced in 1980s. Work-family conflicts increases when work interferes in family life, mostly for individuals with responsibilities toward being a guardian or care taker, (Choo, Desa, \& Abu Hassan Asaari, 2016). Traditional roles suggest that men should first focus on work and women on family, as breadwinners and homeworkers respectively, but nowadays these assigned roles disdain increasingly. Most of males are rejecting roles focusing on work only; thus, competing companies are now offering 'family-friendly' benefits for both parents (mother and father) not only to attract but to retain employees, (Powell, Greenhaus, Allen, \& Johnson, 2018). Even when talking about gender, there is less relationship between flexible working arrangements and work-life conflict. Researches have shown that telecommuting leads toward more work-life conflicts (Chung \& Lippe, 2018).

(Azara, Khana, \& Van Eerdeb, 2018) declared that employees, exposed to the conflict between roles in the work and non-work domains, without family and family care responsibilities

\subsection{Job Satisfaction}

Job satisfaction can be defined as working harmony provided by work itself or an emotional attitude and positive feeling. Classification of job satisfaction has been divided into categories as past studies made the concept of job satisfaction for its identification. They used five facets of job satisfaction, (Özpehlivana \& Zafer Acar, 2015). Satisfied workers yield 
more, deliver higher quality of work than unsatisfied workers, and improve an organization's competitiveness, productivity and success. On other hand, unsatisfied workers are more frequently late for jobs, absent from work, and evoked to leave the organization, (Andrade, $\mathrm{H}$. Westover, \& A. Kupka, 2019).

(Azara, Khana, \& Van Eerdeb, 2018) cited, quitting from adverse working environment is next to low job satisfaction and higher work-life conflict. Evidences have been found in support of this theory. Employees' absenteeism and intention to stay can be predicted by level of job satisfaction. (Baeza, Gonzalez, \& Wang , 2018), how people feel about their jobs, is usually their work attitude, indicating their job satisfaction, not only reflects an overall opinion about a worker's well-being, but relationship to important outcomes.

\subsection{Flexible Working Arrangements and Work-Life Balance}

(Giovanis, 2018) reported that flexible working arrangements provides employees control over their jobs and autonomy, in work-life balance and job satisfaction resulting in increased productivity. Evidences shows that flexibilities provide balance between work and life especially during parenthood, (Chung \& Lippe, 2018). According to (Demeroutia, Derks, ten Brummelhuis, \& B. Bakker, 2014), family situation of organizations`employee is important, and that telecommuting and flexible working are not helpful for employees with a partner and/or child but for singles only. Working from home has various effects on work-family conflict, the more worker works remotely, the lower the conflict work-to-life, but higher life-to-work, (Shockley \& D. Allen, 2010).

(Andrade, H. Westover, \& A. Kupka, 2019) said that by studying different countries we see that for most employees across the 37 countries, it is not the perception that work often interferes with family life, but the truth most likely in India and least likely to Georgia, Suriname, Taiwan, Hungary, Estonia, and Austria. (Azara, Khana, \& Van Eerdeb, 2018), flexible working arrangements helps workers to cope with work-life conflicts. These flexibilities enable families to create time for parenting and other responsibilities. They showed that flexible arrangements reduce work-family conflicts.

\subsection{Flexible Working Arrangements and Job Satisfaction}

(Andrade, H. Westover, \& A. Kupka, 2019) concluded in their research that employers are encouraged to implement strategies to enhance job satisfaction and work-life balance through work arrangements and rewards, which will not only positively impact their firms but increase productivity. They also reported that there is clear linear relationship of schedule flexibility with employee`s job satisfaction as if working from home increases employee`s job satisfaction but working on weekends negatively impact worker`s satisfaction.

(Azara, Khana, \& Van Eerdeb, 2018), based on comparing actual outcomes with desired outcome, employees' emotional reaction defines their job satisfaction. Overall, flexible arrangements are significantly related to the job satisfaction of employees. (Wheatley, 2016) suggested that flexible working arrangements provides women specific advantages as, compared to men, their job satisfaction is more likely to be decreased by work-life conflicts as they are more often 'burdened' by household contribution. 


\section{Mll Macrothink}

(Baeza, Gonzalez, \& Wang, 2018) concluded that in collectivistic and developing economy, flexibilities act as important antecedent. In collective societies, family social support is common. Might be a reason of less work-family conflict for women professionals. (Kipkoech K. V., 2018), argues that flexible work arrangements (flexible time, shift schedules) enable employees to manage their both responsibilities harmoniously. Thus, enhance commitment, engagements and quality of delivering service in public hospitals, resulted in client satisfaction. Research conducted by (Mas-Machuca, Mirabent, \& Alegre, 2016) concluded that flexibility provides job autonomy in managing time and work. Family-supportive work cultures were usually related to higher employees' satisfaction. Employee outcome improves automatically, if autonomy is provided to employees in decision making and supervisor support by managers.

\subsection{Work-Life Balance and Job Satisfaction}

(Andrade, H. Westover, \& A. Kupka, 2019) proved that interference of work with family negatively impact job satisfaction of employees after their research on almost 37 countries. (Adikaram \& V.K. Jayatilake , 2016) cited in their research that firms should provide work-life balance facilities to their workers, so that employees can perform their tasks effectively and lead organizations to the success. When workers are satisfied with their jobs, they become loyal and committed to the organization.

(Mungania, Waiganjo, \& Kihoro , 2016) suggested, work-life balance practices generally have positive impact on individuals and organizational productivity. Pfizer Canada reported a $30 \%$ productivity increase in its translation department when employees were provided with flexible work arrangements (work shifts/job sharing, flextime) and specifically telecommuting. Focusing on customer service specifically KPMG has reported that allowing employees to take emergency time off to attend to care responsibilities has been a driving force behind their retention and superlative services provision. (Arif \& Aftab Farooqi, 2014) cited that they found recognition is related with work-life balance, which directs to employee's satisfaction and the effects of identification or recognition for the employee's effort are reflected in their satisfaction. Workers feel more satisfaction with their work and family when they avail the advantages of work-life balance programs provided by their bosses.

\subsection{Theoretical Framework}

To analyze the research purpose, a following model was constructed, and the variables are generating from past research papers. Thus, the taxonomy of this study comprises flexible working arrangement in relation to work-life balance and job satisfaction, and with mediating role of work-life balance, as depicted in the Figure below. 
INDEPENDENT VARIABLE

FLEXIBLE WORKING

ARRANGEMENTS

1. FLEXIBLE HOURS

2. CONTRACTUAL

WORKING

3. WORK SHIFTS

4. TELECOMMUTING
DEPENDENT VARIABLES

WORK LIFE BALANCE

JOB SATISFACTION

Figure 1. Taxonomy developed by: Researcher

\subsection{Hypothesis}

Ha 1: there is significant relationship of flexible working arrangement with work-life balance of public university employees

Ha 2: significant relationship of flexible working arrangement with job satisfaction of public university employees

Ha 3: significant relationship of work-life balance with job satisfaction of public university employees.

\section{Research Methodology}

\subsection{Research Design}

Impact of one variable on other one is focused; thus, it`s a causal research, (Sondhi, 2011). The quantitative research method was used.

\subsection{Research Organization}

Employees of public universities of Karachi city.

\subsection{Population}

Respondents not only belongs to top to lower management but non-management level as well, from more than nine different public universities all over the city.

\subsection{Sampling}

Respondents are selected on basis of convenience sampling. (Bernard, 2006)

\subsection{Respondents}

211 responses were received. Respondents of this research belong to 25 to greater than 45 years age with different employment levels, i.e., from top to lower management, non-management employees are also included, with different marital status. Most of the 
respondents are married.

\subsection{Data Collection}

\subsubsection{Primary Data}

Primarily data has been collected through manual and online distribution of questionnaire. Moreover, discussions have also been conducted to get the better understanding regarding views or beliefs of respondents.

\subsection{Questionnaire designing}

Questionnaire is comprised of four sections. The last section gathered information on demographic profile of respondents. Section-I covered the Independent variable i.e. flexible working arrangements consist of four arrangements i.e. flexible hours, contractual working, work shifts and telecommuting, (Kipkoech K. V., 2018) and (Sumaiti, 2010). Section-II consist of questions to evaluate work-life balance by using scale of (Smeltzer, et al., 2016). Include four items; work interference with personal life, sufficiency of time, time spent in recreation activities, and the social benefits of the company. Section-III consist of questions about job satisfaction. Psychometric properties of single-item overall measures have been used to assess job satisfaction, (Dolbier, Webster, McCalister, Mallon, \& Steinhardt, 2005). Thus, used five facets of job satisfaction - with coworkers, the supervisor, the nature of the job itself, measuring pay, and with promotion, (Nagy, 2002) and (Scarpello \& Campbell, 1983).

\section{Analysis}

\subsection{Response Rate}

Table 1.

\begin{tabular}{|c|c|c|c|}
\hline Universities & $\begin{array}{c}\text { Questionnaire } \\
\text { Distributed }\end{array}$ & $\begin{array}{c}\text { Questionnaire } \\
\text { Returned }\end{array}$ & Response\% \\
\hline University of Karachi & 45 & 39 & 87 \\
\hline $\begin{array}{c}\text { NED University of Engineering and } \\
\text { Technology }\end{array}$ & 30 & 25 & 83 \\
\hline Karachi Medical \& Dental College & 15 & 09 & 60 \\
\hline Dow University of Health Sciences & 30 & 24 & $\mathbf{8 0}$ \\
\hline Shaheed Benazir Bhutto University & 15 & 10 & 67 \\
\hline Sindh Madressa-tul-Islam University & 30 & 27 & 90 \\
\hline $\begin{array}{c}\text { Federal Urdu University of Arts, } \\
\text { Science and Technology }\end{array}$ & 30 & 27 & 90 \\
\hline Jinnah Sindh Medical University & 20 & 18 & 90 \\
\hline $\begin{array}{c}\text { Dawood University of Engineering and } \\
\text { Technology }\end{array}$ & 20 & 18 & 90 \\
\hline OTHERS & 15 & 14 & 93 \\
\hline Total & 250 & 211 & $\mathbf{8 4 \%}$ \\
\hline
\end{tabular}

It is considered as the sign of successfulness of a survey-based study, (Hafeez \& Akbar, 2015). In this research approximately 250 questionnaires were distributed among more than nine different public universities of Karachi from which 211 questionnaires were returned with the total response rate of $84 \%$, as shown in above table. 


\subsection{Demographic Analysis}

Most of the respondents were male (60.6\%). Ratio of married respondents was $59.29 \%$. Maximum of the respondents in sampled universities worked at middle level management $(68.72 \%)$. Most of the respondents were teachers or professors.

\subsection{Composite Reliability}

All the values are $<0.07$, i.e. the normally used threshold value. Thus, accepted reliability value range, (HAIR, Black, Babin, \& Andersen, 2010).

Table 2.

\begin{tabular}{|c|c|}
\hline Variables & Composite Reliability \\
\hline Flexible Working Arrangements & $\mathbf{0 . 8 6 2}$ \\
\hline Job Satisfaction & $\mathbf{0 . 7 8 9}$ \\
\hline Work-Life Balance & $\mathbf{0 . 8 6 0}$ \\
\hline
\end{tabular}

\subsection{Factor Loadings Significant}

Construct with the loading of. 5 would be considered as strong.

Table 3.

\begin{tabular}{|c|c|c|c|c|}
\hline Variables & Constructs & Item Loading & T-Values & P-Values \\
\hline $\begin{array}{c}\text { Flexible Working } \\
\text { Arrangements }\end{array}$ & FH.1 & $\mathbf{0 . 5 2 1}$ & $\mathbf{5 . 1 9 8}$ & $\mathbf{0 . 0 0 0}$ \\
\hline & FH.2 & $\mathbf{0 . 5 5 2}$ & $\mathbf{4 . 1 6 4}$ & $\mathbf{0 . 0 0 0}$ \\
\hline & FH.3 & $\mathbf{0 . 5 2 2}$ & $\mathbf{5 . 9 0 1}$ & $\mathbf{0 . 0 0 0}$ \\
\hline & FH.4 & $\mathbf{0 . 5 9 5}$ & $\mathbf{3 . 9 3 9}$ & $\mathbf{0 . 0 0 0}$ \\
\hline & WS.1 & $\mathbf{0 . 7 6 1}$ & $\mathbf{4 . 4 6 4}$ & $\mathbf{0 . 0 0 0}$ \\
\hline & WS.2 & $\mathbf{0 . 7 2 2}$ & $\mathbf{3 . 6 6 6}$ & $\mathbf{0 . 0 0 0}$ \\
\hline & WS.3 & $\mathbf{0 . 5 6 0}$ & $\mathbf{1 0 . 8 7 0}$ & $\mathbf{0 . 0 0 0}$ \\
\hline & WS.4 & $\mathbf{0 . 6 6 6}$ & $\mathbf{5 . 8 7 9}$ & $\mathbf{0 . 0 0 0}$ \\
\hline & CW.1 & $\mathbf{0 . 5 4 5}$ & $\mathbf{5 . 3 6 5}$ & $\mathbf{0 . 0 0 0}$ \\
\hline & CW.2 & $\mathbf{0 . 4 7 5}$ & $\mathbf{1 1 . 4 3 4}$ & $\mathbf{0 . 0 0 0}$ \\
\hline & CW.4 & $\mathbf{0 . 6 0 0}$ & $\mathbf{2 . 4 1 8}$ & $\mathbf{0 . 0 1 6}$ \\
\hline & TC.1 & $\mathbf{0 . 4 3 0}$ & $\mathbf{2 . 9 1 8}$ & $\mathbf{0 . 0 0 4}$ \\
\hline & TC.4 & $\mathbf{0 . 4 2 6}$ & $\mathbf{9 . 3 9 3}$ & $\mathbf{0 . 0 0 0}$ \\
\hline Job Satisfaction & JS.1 & $\mathbf{0 . 7 8 9}$ & $\mathbf{1 1 . 4 9 0}$ & $\mathbf{0 . 0 0 0}$ \\
\hline & JS.3 & $\mathbf{0 . 5 7 7}$ & $\mathbf{1 0 . 9 1 6}$ & $\mathbf{0 . 0 0 0}$ \\
\hline & JS.7 & $\mathbf{0 . 5 8 1}$ & $\mathbf{1 1 . 5 1 8}$ & $\mathbf{0 . 0 0 0}$ \\
\hline & JS.9 & $\mathbf{0 . 8 1 6}$ & $\mathbf{9 . 8 4 5}$ & $\mathbf{0 . 0 0 0}$ \\
\hline Work-Life Balance & WLB1 & $\mathbf{0 . 7 2 2}$ & $\mathbf{6 . 9 9 2}$ & $\mathbf{0 . 0 0 0}$ \\
\hline & WLB3 & $\mathbf{0 . 6 9 9}$ & $\mathbf{7 . 4 6 9}$ & $\mathbf{0 . 0 0 0}$ \\
\hline & WLB8 & $\mathbf{0 . 7 2 0}$ & $\mathbf{3 . 2 6 5}$ & $\mathbf{0 . 0 0 1}$ \\
\hline & WLB9 & $\mathbf{0 . 7 3 3}$ & $\mathbf{4 . 8 3 3}$ & $\mathbf{0 . 0 0 0}$ \\
\hline & WLB10 & $\mathbf{0 . 8 3 7}$ & $\mathbf{3 . 5 0 8}$ & $\mathbf{0 . 0 0 0}$ \\
\hline & & & \\
\hline
\end{tabular}

Ten constructs related to independent variable flexible working arrangements has loading values above than 0.50 while three items CW.3, TC.2, TC.4 eliminated due to irrespective loading. TC. $1 \&$ TC. 4 are still included although their values are less than 0.5 . While, nine 
constructs related to dependent variable, work-life balance and job satisfaction has loading values above than 0.50; while, some items WLB2, 4, 5, 6, 7 and JS.2, 4, 5, 6, 8 and 10 eliminated due to irrespective loading.

\subsection{Convergent Validity}

Table 4.

\begin{tabular}{|c|c|c|c|c|}
\hline Variables & $\begin{array}{c}\text { No. of } \\
\text { items }\end{array}$ & $\begin{array}{c}\text { CRONBACH'S } \\
\text { ALPHA }\end{array}$ & rho_A & $\begin{array}{c}\text { Composite } \\
\text { Reliability }\end{array}$ \\
\hline $\begin{array}{c}\text { Flexible Working } \\
\text { Arrangements }\end{array}$ & $\mathbf{1 3}$ & .828 & .843 & .862 \\
\hline Work-Life Balance & $\mathbf{0 5}$ & .648 & .693 & .789 \\
\hline Job Satisfaction & $\mathbf{0 4}$ & .797 & .804 & .860 \\
\hline
\end{tabular}

According to (GASKIN, 2017), it should be above 0.5. Table shows the Cronbach's alpha value of all the variables in which all the variables has $(\alpha \approx 0.7)$, which determines the questions for job satisfaction and work-life balance can be viewed as acceptable as well as predictable.

Consistency is being showed in data of above table as composite reliability is fine as an indication of convergent validity, (GASKIN, 2017). For all the questions related to dependent as well as independent variables, respondents having similar thoughts showed that most of them were at same pace.

\subsection{Discriminant Validity}

Its results are satisfactory when the constructs are having an AVE loading more than 0.5 which means that minimum $50 \%$ of variance was taken by constructs, (Chin, 1998).

The tables for Discriminant Validity are given below.

\subsubsection{Fornell-Larcker Criterion}

Table 5.

\begin{tabular}{|l|l|l|l|}
\hline & $\begin{array}{l}\text { Flexible Working } \\
\text { Arrangements }\end{array}$ & Job Satisfaction & Work-Life Balance \\
\hline $\begin{array}{l}\text { Flexible Working } \\
\text { Arrangements }\end{array}$ & $\mathbf{0 . 5 7 6}$ & & \\
\hline Job Satisfaction & $\mathbf{0 . 5 1 1}$ & $\mathbf{0 . 7 0 0}$ & \\
\hline Work-Life Balance & $\mathbf{0 . 4 5 4}$ & $\mathbf{0 . 6 3 2}$ & $\mathbf{0 . 7 4 4}$ \\
\hline
\end{tabular}

On the off-diagonal, we have the correlations as job satisfaction correlates with flexible arrangements at point 0.511 and on-diagonal, we have the square roots of the AVE, now the square root must be greater than any of those inter factor correlations. So, looks like we are good at the lowest one we have here is 0.576 and it is greater than those correlations, (GASKIN, 2017). 
4.6.2 Heterotrait-Monotrait Ratio: (HTMT)

Table 6.

\begin{tabular}{|l|l|l|l|}
\hline & $\begin{array}{l}\text { Flexible Working } \\
\text { Arrangements }\end{array}$ & Job Satisfaction & Work-Life Balance \\
\hline $\begin{array}{l}\text { Flexible Working } \\
\text { Arrangements }\end{array}$ & & & \\
\hline Job Satisfaction & $\mathbf{0 . 6 6 2}$ & & \\
\hline Work-Life Balance & $\mathbf{0 . 5 4 0}$ & $\mathbf{0 . 8 4 9}$ & \\
\hline
\end{tabular}

According to (GASKIN, 2017), this is the measurement of discriminant validity, essentially whether these are the same or different in factors. The threshold we look for here is 1 . The values should be less than 1 as it indicates that these are different factors. Note that the lowest they are the more different they are. Thus, in this case we do have discriminant validity because our HTMT is less than 1.

\subsection{Latent Variable Correlation}

Table 7.

\begin{tabular}{|c|c|c|c|}
\hline & $\begin{array}{c}\text { Flexible Working } \\
\text { Arrangements }\end{array}$ & Job Satisfaction & Work Life Balance \\
\hline $\begin{array}{c}\text { Flexible Working } \\
\text { Arrangements }\end{array}$ & 1 & 0.511 & 0.454 \\
\hline Job Satisfaction & 0.511 & 1 & 0.632 \\
\hline Work Life Balance & $\mathbf{0 . 4 5 4}$ & $\mathbf{0 . 6 3 2}$ & 1 \\
\hline
\end{tabular}

The above table demonstrate the positive relationship between variables of this study. By showing positive sign with them, flexible working arrangements brings a significant effect on work-life balance and job satisfaction of public university employees. Furthermore, with 0.632 work-life balance has highest relationship with job satisfaction if compared with other variables. Flexible working arrangement has greater degree of relationship with job satisfaction that is 0.511 than work-life balance. This figurative explanation proves that flexible working arrangement has great importance in satisfying public university employees by mediating role of work-life balance.

\subsection{Model Fit Measures}

The correlation between all constructs is assessed by saturated model. While model structure is considered by estimated model and is based on total effect scheme. 
Table 8 .

\begin{tabular}{|l|c|c|}
\hline \multicolumn{2}{|c|}{ Fit Summary } \\
\hline SRMR & Saturated Model & Estimated Model \\
\hline d_ULS & 0.091 & 0.091 \\
\hline d_G & 2.104 & 2.104 \\
\hline Chi-Square & 0.580 & 0.580 \\
\hline NFI & 649.675 & 649.675 \\
\hline
\end{tabular}

\subsection{Hypothesis Testing}

R-squared measures goodness-of-fit for linear regression models, (Frost, 2019).

Table 9.

\begin{tabular}{|c|c|c|}
\hline Variables & R-Square & Adjusted R-Square \\
\hline Job Satisfaction & 0.463 & 0.458 \\
\hline Work-Life Balance & 0.206 & 0.202 \\
\hline
\end{tabular}

R-square value shows $46.3 \%$ and $20.6 \%$ of variance in the dependent variable. Considering other variable remain constant, work-life balance has $20.6 \%$ and job satisfaction has $46.3 \%$ variance for flexible working arrangements, which is moderate percentage. This percentage shows that employees of public universities (Karachi) wants moderately more and are attracted towards different flexible arrangements to maintain their work-life conflicts and satisfaction with their jobs.

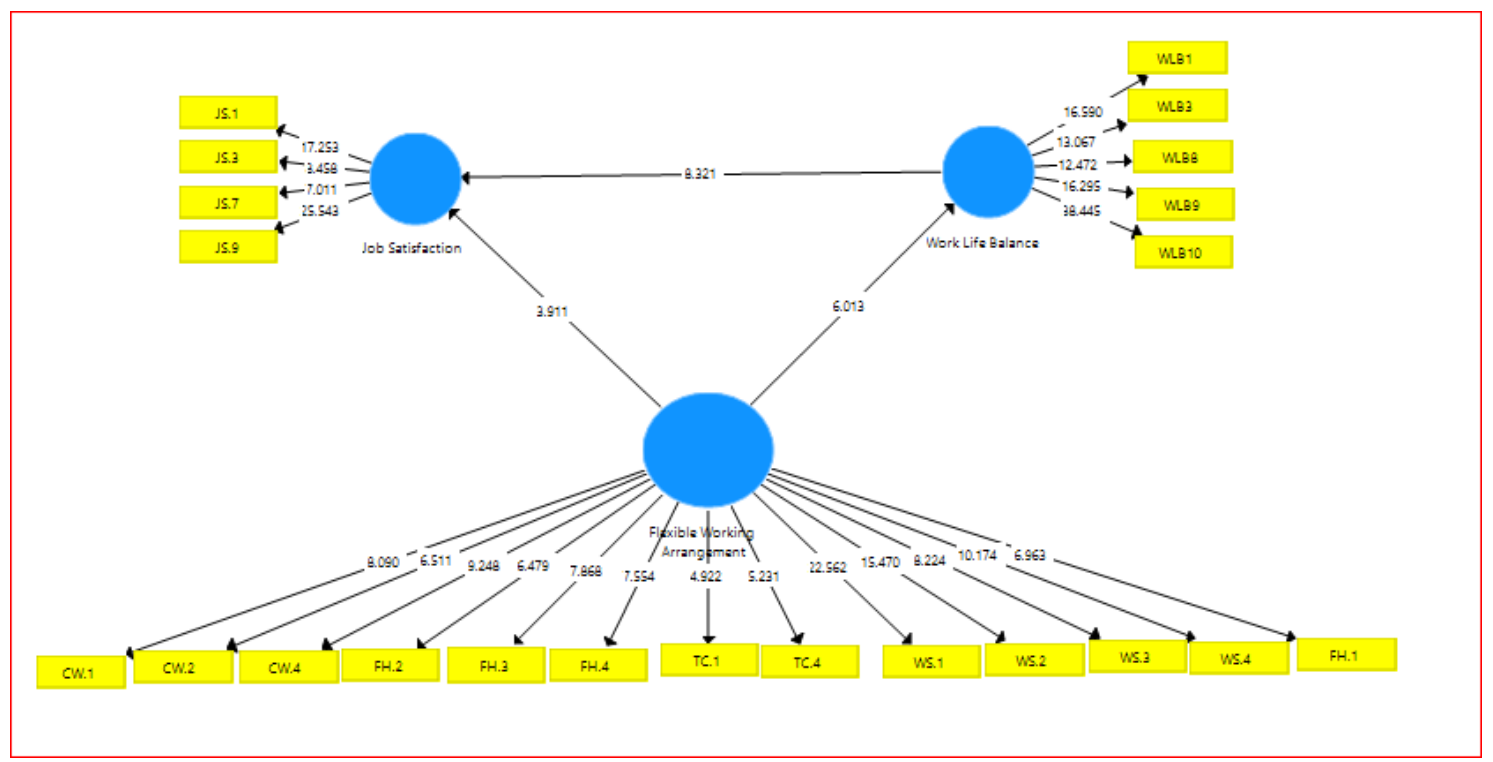

Figure 2. 


\section{Macrothink Institute ${ }^{\mathrm{TM}}$}

The t-value, $<1.96(\mathrm{p}<.005)$ shows significant relationship at 95\% confidence level $(\alpha=$ 0.05). Whether the relationship between measured and latent variables are significant or not, shown above by path diagram in figure 2 .

Table 10.

\begin{tabular}{|l|c|c|}
\hline \multicolumn{3}{|c|}{ Descriptive statistics } \\
\hline \multicolumn{1}{|c|}{ Variables } & T-Statistics & P values \\
\hline $\begin{array}{l}\text { Flexible Working Arrangements > Work-Life } \\
\text { Balance }\end{array}$ & 5.774 & 0.000 \\
\hline $\begin{array}{l}\text { Flexible Working Arrangements > Job Satisfaction } \\
\text { Work-Life Balance > Job Satisfaction }\end{array}$ & $\mathbf{3 . 6 9 1}$ & $\mathbf{0 . 0 0 0}$ \\
\hline
\end{tabular}

Furthermore, above table also shows $\mathrm{P}$ value $0.000<0.05$ indicates (Rumsey, 2016) the strong evidence.

\section{Summary of Hypothesis Results}

Table 11.

\begin{tabular}{|c|l|c|}
\hline Ha 1 & $\begin{array}{l}\text { Hignificant relationship of flexible working arrangement with } \\
\text { work-life balance of public university employees }\end{array}$ & Supported \\
\hline Ha 2 & $\begin{array}{l}\text { Significant relationship of flexible working arrangement with job } \\
\text { satisfaction of public university employees }\end{array}$ & Supported \\
\hline Ha 3 & $\begin{array}{l}\text { Significant relationship of work-life balance with job satisfaction } \\
\text { of public university employees }\end{array}$ & Supported \\
\hline
\end{tabular}

\section{Discussions}

The results indicate that flexible working arrangements have impact on both the dependent variables i.e. work-life balance and job satisfaction of public universities' employees, Karachi. In today's corporate world, flexible arrangements have become main priorities of HR, senior executives and practitioners of organizations.

Many authors emphasized on the role of managers, to reduce work-life conflicts as they can increase flexibility in terms of work hours. By prioritized efforts, workers can work fewer hours. According to (Mas-Machuca, Mirabent, \& Alegre, 2016), pursuance of high level of work-life balance become easier for employees, if managers supports work-life initiatives. Working flexibilities not only provide job autonomy to employees to manage their schedules but give organizational pride which makes them committed and more engaged. Thus, productivity increases, as they feel higher level of satisfaction by maintaining balance between work and family life.

Findings suggested, where work flexibilities (i.e. flex hours, telecommuting, work shifts and contractual working) are provided to employees, organizations would experience lower level of work-life conflicts. But (Russell, O'Connell, \& McGinnity, 2009) argued that employees suffer high work-life conflicts who engaged in telecommuting as compared to who do not. 
Telecommuting is therefore appearing to aggravate tensions between work and family life rather than resolving them. Our research agrees with the explanation of (Sumaiti, 2010) that work-life balance positively correlates with telework. (Anderson \& Kelliher, 2010) also showed that than non-flexible workers, flexible workers have higher level of job satisfaction.

Our results seem to indicate that employees that feel comfortable and flexible in their jobs and have an effective work-life balance are more satisfied with their jobs and companies. Previous researches pointed out only one or two flexibilities, (Abid \& Barech , 2017), in different sectors other than public education, (Giovanis, 2018), or in only one public college which cannot give a broader view about research and responses of people working in public institutions, (Hashim, Ullah, \& Azizullah Khan, 2017). So, flexible arrangements are full mediator between employees' work-life balance and job satisfaction. Moreover, in our research Cronbach's alpha for flexible working arrangement $=0.828$, work-life balance $=0.648$ and job satisfaction $=0.797$ i.e. $<0.60$, sufficient for research purpose.

\section{Conclusion}

This study does not only contribute in academics but also in different areas like insurance company, banking sector, pharmaceutical companies, shopping centers etc.

To conclude, this research paper revealed that for decreasing life and works conflicts and increasing job satisfaction, flexible arrangements act as strong predictor. The analysis shows that public university employees would have lower level of satisfaction if they have more work-life conflicts. This implies that great importance is being attached to non-monetary aspects of the job by workers, which could be improved by other flexibilities. Research in Mexico provide evidences that in job satisfaction, high role of flexibility has been found, especially among young generation; particularly millennials, who have less dependents and responsibilities. On the other hand, where higher percentage of employees responded to our survey were married, suggesting that flexible working arrangements may be more salient for married than single employees may be because of more responsibilities or dependents like children, aging parents or others. The research also indicates clearly that flexible working arrangements may give positive impact to male as well as female employees to maintain the balance between task in the office and obligation toward the family. Similarly, other authors also justified that flexibilities and work-life balance have nothing to do with gender, while others emphasized that they are more important in collectivistic society and developing economy. In our research, all employment levels were considered to get more broader view at each stage. Conducting this research in public educational sector highlighted that by providing workers with different flexibilities not only help teaching staff to serve more to students to make better quality career life but to reduce absenteeism and increase productivity at all employee levels, as they get higher satisfaction and better balance between work and life through various flexibilities. This discipline and sincerity of employees towards their work would not only give moral values to our upcoming generation but also be beneficial for our economy in long run as human resource plays vital role in any organizational growth. Employees of public universities are government's servant. Thus, they should also be treated as human capital treated in other successful companies. Worth of flexible arrangements must 
be understood by public universities and efforts should be made to provide flexible environment that supports to meet the needs of their staff. Hence, for further development of organizations, to achieve their objectives, job satisfaction and work-family conflict are vital aspects.

Finally, the challenge of a successful implementation of working flexibilities lies collectively on employers, policymakers, and society in general. Managers should also recognize that employee values flexibilities and considers it very crucial for job satisfaction. Findings suggested that if flexibilities would be given to university workers of Karachi, could help to strengthen their emotional status at work and relationship with the organization as workers become more loyal and committed. Thus, can easily be retained and will save cost of recruiting new employees. Therefore, advices are given to organizations and HR departments to value the hard-work of their employees.

Our findings extend previous work-life research that focused on employee`s job satisfaction and provide evidences about relationship; work-life balance is positively related with job satisfaction. In addition, flexible working arrangements have significant impact on both work-life balance and employees` job satisfaction in public university of Karachi, Pakistan. Although flexible arrangements have been linked to other constructs like productivity, organization's engagement and job quitting behavior, it is the first time that we link different types of flexibilities with work-life and job satisfaction together and found the mediating role of work-life balance with job satisfaction, especially in public university sector, in the work-life literature. Previous researches pointed out that flexibilities like telecommuting has a negative influence on managing balance between work and personal life. Our research shows that this effect is strong and have positive relation. Thus, work-life balance act as strong mediator. (AZIRI, 2011).

\subsection{Recommendations}

The study recommends the use of work shifts, more in universities as one strategy of flexible work, as they have stronger significance than other arrangements. Also, contractual working is advocated to be a positive contribution in employment strategies. Flexitime needs proper scheduling. Job flexibility was considered significant to increase job satisfaction as well as maintain work-life conflicts. It is evident that teaching profession is tough and exhausting when join with personal life responsibilities, there work-life balance would hardly be sustained as human resources are rarely used efficiently. Since working too much hours might be lessening the efficacy of employees. They ought to be appreciated by their expertise, knowledge and involvement, instead of working hours. Assign job duties according to the skills of your subordinate. Over burdening will not make them habitual to work more but results in burnout; hence, dissatisfaction. Flexible working environment plays a great role in retaining valuable employees.

For future research, it is recommended that same study could be directed on a large-scale sample, in other cities, with a few more factors and with more arrangements like compressed week, work sharing, annualized hours etc. that might be included in order to increase the scope of the research and to get more reliable and valid results or by using different method 
of data collection, increasing number of samples so that findings will be more accurate.

\subsection{Research Limitation}

Not every public university of Karachi is covered for the collection of responses. Convenience sampling is used in this research. This research is a primary research in which data collection is done through survey through questionnaire in order to gather relevant responses from the sample. Sample size does not provide the detailed and thorough examination but satisfies the overall research objective. This study included different employees from different levels of different universities; some employees who work in top or middle management can understand working flexibilities, as are offered to them, while other does not. Some employees, for example, working full time and using telework to deal with troubleshooting calls after working hours, so it was not very accurate picture about how people want to telework or use other flexibilities. Some other variables are being ignored in estimating the flexible working arrangements, job satisfaction and work-life balance because of time constrain.

\section{References}

Abid, S., \& Barech , D. (2017). THE IMPACT OF FLEXIBLE WORKING HOURS ON THE EMPLOYEES PERFORMANCE. International Journal of Economics, Commerce and Management , 450-466.

Adikaram, D., \& V.K. Jayatilake, D. (2016). IMPACT OF WORK LIFE BALANCE ON EMPLOYEE JOB SATISFACTION IN PRIVATE SECTOR COMMERCIAL BANKS OF SRI LANKA. International Journal of Scientific Research and Innovative Technology, 17-31.

Aguilera, A., Lethiais, V., Rallet, A., \& Proulhac, L. (2016). Home-based telework in France: Characteristics, barriers and perspectives. Transportation Research Part A, 1-11. https://doi.org/10.1016/j.tra.2016.06.021

Anderson, D., \& Kelliher, C. (2010). Doing more with less? Flexible working practices and the intensification of work. Human Relations, 83-106. https://doi.org/10.1177/0018726709349199

Andrade, M. S., H. Westover, J., \& A. Kupka, B. (2019). The Role of Work-Life Balance and Worker Scheduling Flexibility in Predicting Global Comparative Job Satisfaction. International Journal of Human Resource Studies, 80-115. https://doi.org/10.5296/ijhrs.v9i2.14375

Anonymous. (2008). Flexible Work Arrangements. Retrieved from Inc. this morning: https://www.inc.com/encyclopedia/flexible-work-arrangements.html

Anonymous. (2015, june). Flexible working and work-life balance. Retrieved from Acas Website:

http://m.acas.org.uk/media/pdf/3/1/Flexible_working_and_work_life_balance_Nov.pdf 
Arif, B., \& Aftab Farooqi, Y. (2014). Impact of Work Life Balance on Job Satisfaction and Organizational Commitment Among University Teachers: A Case Study of University of Gujrat, Pakistan. INTERNATIONAL JOURNAL OF MULTIDISCIPLINARY SCIENCES AND ENGINEERING, 24-29.

Ashoush, M. A.-L., Elsayed, A., \& Younis, R. (2015). FLEXIBLE WORK ARRANGEMNTS: RELATED TOPICS AND DIRECTIONS. $n$ Journal of Business Studies Quarterly, 36-45.

Azara, S., Khana, A., \& Van Eerdeb, W. (2018). Modelling linkages between flexible work arrangements' use and organizational outcomes. Journal of Business Research, 134-143. https://doi.org/10.1016/j.jbusres.2018.06.004

AZIRI, B. (2011). JOB SATISFACTION: A LITERATURE REVIEW. MANAGEMENT RESEARCH AND PRACTICE, 77-86.

Baeza, M. A., Gonzalez, J. A., \& Wang, Y. (2018). Job flexibility and job satisfaction among Mexican professionals: a socio-cultural explanation. Employee Relations, 1-23. https://doi.org/10.1108/ER-12-2016-0236

Bernard, H. R. (2006). Research Methods In Anthropology : Qualitative and Quantitative Approaches : fourth edition. New York: ALTAMIRA PRESS A Division of Rowman \& Littlefield Publishers, Inc.

Caillier, J. G. (2018). Do flexible work schedules reduce turnover in U.S. federal agencies? The Social Science Journal, 108-115. https://doi.org/10.1016/j.soscij.2017.09.005

Chin, W. W. (1998). The Partial least squares approach to structural equation modeling. Mahwah, NJ, US: Lawrence Erlbaum Associates Publishers.

Choo, J. L., Desa, N., \& Abu Hassan Asaari, M. (2016). http://sass.sciedupress.com Studies in Asian Social Science Vol. 3, No. 1; 2016 Published by Sciedu Press 21 ISSN 233Flexible Working Arrangement toward Organizational Commitment and Work-Family Conflict. Studies in Asian Social Science, 21-36. https://doi.org/10.5430/sass.v3n1p21

Chung, H., \& Der Lippe, T. (2018). Flexible Working, Work-Life Balance, and Gender Equality. Social Indicators Research, 1-17. https://doi.org/10.1007/s11205-018-2025-x

Chung, H., \& Lippe, T. V. (2018). Flexible Working, Work-Life Balance, and Gender Equality. Introduction Social Indicators Research, 1-17. https://doi.org/10.1007/s11205-018-2025-X

Demeroutia, E., Derks, D., ten Brummelhuis, L., \& Bakker, A. B. (2014). New Ways of Working: Impact on Working Conditions, Work-family Balance, and Well-being. The Impact of ICT on Quality of Working Life, 123-141. https://doi.org/10.1007/978-94-017-8854-0_8

Dessler, G. (2008). Human Resource Management. (11thed.). New York: New Jersey: Pearson Education Limited. 


\section{Macrothink}

International Journal of Human Resource Studies ISSN 2162-3058 2020, Vol. 10, No. 1

Dolbier, C. L., Webster, J., McCalister, K., Mallon, M., \& Steinhardt, M. (2005). Reliability and Validity of a Single-item Measure of Job Satisfaction. American Journal of Health Promotion, 194-198. https://doi.org/10.4278/0890-1171-19.3.194

Frost, J. (2019, july). How To Interpret R-squared in Regression Analysis; https://statisticsbyjim.com/regression/interpret-r-squared-regression/. Retrieved from https://statisticsbyjim.com/regression/interpret-r-squared-regression/

GASKIN, J. (2017, june 14). SmartPLS 3 factor analysis. https://www.youtube.com/watch?v=J_etGiwbOoM.

Gerdenitsch, C., Kubicek, B., \& Korunka, C. (2015). Control In Flexible Working Arrangements: when freedom becomes duty. Journal of Psychology, 61-69. https://doi.org/10.1027/1866-5888/a000121

Giovanis, E. (2018). The relationship between flexible employment arrangements and workplace performance in Great Britain. International Journal of Manpower, 51-70. https://doi.org/10.1108/IJM-04-2016-0083

Hafeez, U., \& Akbar, W. (2015). Impact of work-life balance on job satisfaction among school teachers of 21st century. Australian Journal of Business and Management Research, $25-37$.

HAIR, J. F., Black, J., Babin, W., \& Andersen, R. (2010). Mutilvariate data analysis (7th ed.). Upper Saddle River, NJ: Pearson Prentice Hall, 280.

Hashim, M., Ullah, M., \& Azizullah, K. D. (2017). IMPACT OF TIME FLEXIBILITY ON EMPLOYEES' PERFORMANCE: A STUDY OF TEACHING FACULTY IN GOVERNMENT COLLEGES OF MANAGEMENT SCIENCES PESHAWAR. City University Research Journal, 206-212.

Hinterseer, T. (2013). Part-time work: Atypical? Precarious? Normal? European Journal of Futures Research, 1-18. https://doi.org/10.1007/s40309-013-0018-1

Kattenbach, R., Demerouti, E., \& Nachreiner, F. (2010). Flexible working times: effects on employees' exhaustion, work-nonwork conflict and job performance. Career Development International , 279-295. https://doi.org/10.1108/13620431011053749

Kipkoech, K. V. (2018). Flexible working arrangements on employee performance in Kericho County referral hospital, Kenya. 1-73.

Kipkoech, V. K. (2017). Flexible Working Arrangement and Performance in Public Hospitals. INTERNATIONAL JOURNAL OF INNOVATIVE RESEARCH \& DEVELOPMENT, 81-85. https://doi.org/10.24940/ijird/2017/v6/i10/OCT17065

Mas-Machuca, M., Mirabent, J. B., \& Alegre, I. (2016). Work-life balance and its relationship with organizational pride and job satisfaction. Journal of Managerial Psychology, 586-602. https://doi.org/10.1108/JMP-09-2014-0272 
Mungania, A. K., Waiganjo, D., \& Kihoro , P. (2016). Influence of Flexible Work Arrangement on Organizational Performance in the Banking Industry in Kenya. International Journal of Academic Research in Business and Social Sciences, 159-172. https://doi.org/10.6007/IJARBSS/v6-i7/2238

Nagy, M. S. (2002). Using a single-item approach to measure facet job satisfaction. Journal $\begin{array}{llll}\text { of Occupational and Organizational Pychology, } & \text { 77-86. }\end{array}$ https://doi.org/10.1348/096317902167658

Özpehlivana, M., \& Zafer Acar, A. (2015). Assessment of a Multidimensional Job Satisfaction Instrument. Procedia - Social and Behavioral Sciences, 283-290. https://doi.org/10.1016/j.sbspro.2015.11.368

Powell, G. N., Greenhaus, J. H., Allen, T. D., \& Johnson, R. E. (2018). ADVANCING AND EXPANDING WORK-LIFE THEORY FROM MULTIPLE PERSPECTIVES. Academy of Management Review, 1-43. https://doi.org/10.5465/amr.2018.0310

Rumsey, D. J. (2016). WHAT A P-VALUE TELLS YOU ABOUT STATISTICAL DATA ; https://www.dummies.com/education/math/statistics/what-a-p-value-tells-you-about-statistica 1-data/.

Russell, H., O'Connell, P., \& McGinnity, F. (2009). The Impact of Flexible Working Arrangements on Work-Life Conflict and Work Pressure in Ireland. ESRI, 73-97. https://doi.org/10.1111/j.1468-0432.2008.00431.x

Scarpello, V., \& Campbell, J. P. (1983). Job satisfaction: are all the parts? Personnel Psychology, 577-600. https://doi.org/10.1111/j.1744-6570.1983.tb02236.x

Shagvaliyeva, S., \& Yazdanifard, R. (2014). Impact of Flexible Working Hours on Work-Life Balance. American Journal of Industrial and Business Management, 20-23. https://doi.org/10.4236/ajibm.2014.41004

Shockley, K. M., \& D. Allen, T. (2010). Investigating the missing link in flexible work arrangement utilization: An individual difference perspective. Journal of Vocational Behavior, 131-142. https://doi.org/10.1016/j.jvb.2009.07.002

Smeltzer, S. C., Cantrell, M., Sharts-Hopko, N., Heverly, M., Jenkinson, A., \& Nthenge, S. (2016). Psychometric Analysis of the Work/Life Balance Self-Assessment Scale. Journal of Nursing Measurement, 5-14. https://doi.org/10.1891/1061-3749.24.1.5

Sondhi, N. (2011). Research Methodology- Concept and Cases. VIKAS PUBLISHING HOUSE PVT. LTD.

Sumaiti, R. S. (2010). The Work Life Balance and Job Satisfaction in Oil and Gas organisations in the UAE context, 2-91.

Wheatley, D. (2016). Employee satisfaction and use of flexible working arrangements. Work, employment and society, 567-585. https://doi.org/10.1177/0950017016631447 


\section{Macrothink}

International Journal of Human Resource Studies

ISSN 2162-3058 2020, Vol. 10, No. 1

Wojcak, E., Bajzikovab, L., Sajgalikova, H., \& Polakova, M. (2016). How to Achieve Sustainable Efficiency with Teleworkers: Leadership Model in Telework. Procedia - Social and Behavioral Sciences, 33-41. https://doi.org/10.1016/j.sbspro.2016.07.111

Yang, S., \& Zheng, L. (2011). The paradox of de-coupling: A study of flexible work program and workers' productivity. Social Science Research, 299-311. https://doi.org/10.1016/j.ssresearch.2010.04.005

Zeytinoglu, I. U., Denton, M., \& Millen Plenderleith, J. (2011). Flexible employment and nurses' intention to leave the profession. The role of support at work. Health Policy, 149-157. https://doi.org/10.1016/j.healthpol.2010.07.017

\section{Copyright Disclaimer}

Copyright for this article is retained by the author(s), with first publication rights granted to the journal.

This is an open-access article distributed under the terms and conditions of the Creative Commons Attribution license (http://creativecommons.org/licenses/by/4.0/). 